\title{
BOTTOM-UP AND TOP-DOWN APPROACHES IN ENGLISH LESSONS
}

\author{
Mannonova Shahnoza Inomjonovna
}

English Teacher At Academic Lyceum of Uwed, Uzbekistan

\section{ABSTRACT}

Top-down and bottom-up approach are essential in teaching English, especially reading and listening. In teaching English at academic lyceums and schools it is required using both of them in order to increase the level effectiveness of learning new theme. Top-down processing leads the learners to have the general idea first and eventually into the details. Bottom-up approach pays attention to small units in the text or listening first and from details to the main idea of the text. The purpose of this article is to give detailed description of top-down and bottom-up approaches and an example of the lesson where these approaches used in the way of activities with some exercises.

KEYWORDS: - Top-down approach, bottom-up approach, teaching English, reading, listening, psycholinguistic model, academic lyceum, pre-intermediate, reading passage, web tool, assessment.

\section{INTRODUCTION}

The psycholinguistic model of receptive types of speech activity (reading and listening) "from the bottom up" opposes the model of understanding and processing information "from the top down". The bottom-up model is based on the idea of reading and listening as sequentially unfolding processes of decoding incoming information "from below", that is, from recognizing graphemes and phonemes to words, from words to sentences, from sentences to super-phrasal units and to understanding the text as a whole. This model explains how information received in the form of graphic or audio signals is transformed and stored in the students' memory of a written or oral message. The bottom-up model not only defines the approach to extracting information from the text, but also outlines the way to form the speech functional system of a foreign language - the piecemeal assimilation of all the main components of this system, their accumulation, integration. The ultimate goal is considered to be the unification of all elements into one whole, that is, the understanding of the text read or listened to.

Top-down and bottom-up approaches in English lessons.

In many cases, students are in a bottom-up learning 
CURRENT RESEARCH JOURNAL OF PHILOLOGICAL SCIENCES 2(12):

155-160, December 2021

DOI: https://doi.org/10.37547/philological-crjps-02-12-30

ISSN 2767-3758

(C)2021 Master Journals

\section{Crossref doi 81 Google}

Accepted21 $1^{\text {th }}$ December, 2021 \& Published $26^{\text {th }}$ December, 2021

mode. They are desperately trying to understand every single word in the text they are listening to. Unfortunately, in many situations this is simply not possible. They are often disappointed and just give up. Therefore, it should be remembered that during top-down text processing, the reader or listener gets a general view of the passage to read or listen to. In the process of processing "from the bottom up", the reader or listener focuses on individual words and phrases and achieves understanding by connecting these detailed elements together, thus creating a single whole.

As teachers, we must be aware of the mental processes that lead to a better understanding of the text. This will help us decide what to do in class to help students read and listen better.

In this article I am going to suggest some ideas for English lessons at academic lyceums or schools where students have pre-intermediate level of English. We define the topic. Good readers and listeners are able to identify the topic of a written or spoken text very quickly. This allows them to process the text more efficiently during the reading process. Before reading or listening, you can ask your students to brainstorm on what they already know about this topic, provide for the characteristics of the genre of the text, or ask what they want to learn from the text/ content (in such cases when they do not have enough prior knowledge on the topic of the text).

We predict and make guesses. Both readers and listeners sometimes use guesses to try and understand what is written in the text or what is being talked about. Ask students to anticipate what will be discussed, to guess or guess the content at a glance or after listening to a small fragment. Further reading/listening will help them confirm their expectations. Use contextual and non-linguistic information (for example, drawings, text presentation and headings for reading, ask who communicates with whom, what and why - for listening).

We pre-teach the key vocabulary. This helps with bottom-up text processing. However, this should not be abused, because then students will not learn to guess the meaning of words from the context. We use the techniques of skimming to read the text and listening for gist. Good readers and listeners are able to perceive the flow of discourse and understand its general essence without being distracted by details. By encouraging students to read or listen in order to grasp the essence, we help them to be prepared for reading and listening to more specific information. In this way, students will use their opportunities to take more for themselves from the top-down study of what is happening. We read and listen for specific information. We often turn to written or spoken text because we want specific details. Students should know how to ignore any other information and find specific information. We can ask our students, for example, to quickly review a movie review and find the name of the actor or director.

We read and listen to understand the details. This also includes listening for conclusions about the attitude, intentions of the speaker, and the like. Such tasks are more demanding and require more intensive listening. It might be a good idea to split the recording into fragments, which will allow students to consult with each other before checking the assignment with the rest of the students.

Now, I will give an example of lesson on reading where students are given a reading passage with top-down and then bottom-up processing activities in turn to achieve desirable result out of the lesson. Top-down processing activity in lesson can be begun with asking some questions to find out students' prior knowledge on the topic of the reading passage: 
CURRENT RESEARCH JOURNAL OF PHILOLOGICAL SCIENCES 2(12):

155-160, December 2021

DOI: https://doi.org/10.37547/philological-crjps-02-12-30

ISSN 2767-3758

(C)2021 Master Journals

crossref do) 8: Google

Accepted21 $1^{\text {th }}$ December, 2021 \& Published $26^{\text {th }}$ December, 2021

- Do you like snow/winter/cold weather?

- Have you ever made anything from ice or snow?

- Can you imagine yourself sleeping in a cold room?

Question like these gives students chance to think about the text's general idea. Top-down processing begins with general idea into small details of the text. Asking students these questions a teacher can rise interest to the text and let them have the main idea of it. They will predict general idea and be ready to read the text with enthusiasm.

Another activity on top-down processing can be mind-mapping on the main idea of the reading passage. In practice I usually show this mind-map before reading the reading passage in order to engage students into reading it with just simple words in a picture.

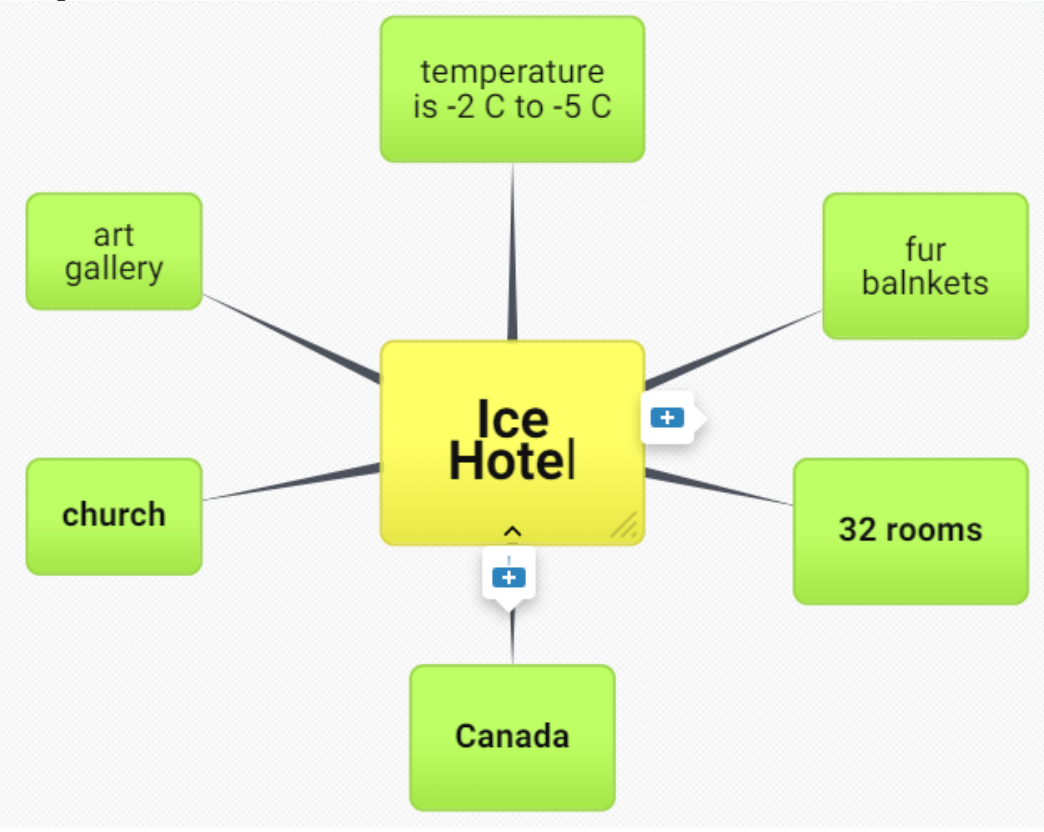

Now, we can read the text. Usually, I give my students time to read according to word count of the text. 
CURRENT RESEARCH JOURNAL OF PHILOLOGICAL SCIENCES 2(12):

155-160, December 2021

DOI: https://doi.org/10.37547/philological-crjps-02-12-30

ISSN 2767-3758

(C)2021 Master Journals

\section{Crossref doi gir Google}

Accepted21 $1^{\text {th }}$ December, 2021 \& Published $26^{\text {th }}$ December, 2021

\section{The Ice Hotel}

\section{A} re you into skiing? Is winter your favorite time of year? If you like snow and ice, maybe you should stay at the Ice Hotel in Quebec, Canada. But, you can only check in to this hotel during the winter. Why? Because this hotel is made entirely of ice and snow!

This amazing hotel is built every December. It has 32 rooms, and 80 people can stay there each night. The hotel has a movie theater, an art gallery, and a church. of course, all of these parts of the hotel are made of ice. In fact, all the furniture, art, lights, and even plates and drinking glasses are made of ice.

Because this hotel is so unusual, it has become very popular. People from all

to over the world come to the Ice Hotel to look at the fantastic ice art, drink and eat from designer ice dishes, and experience the unique atmosphere. Some couples have even gotten married in the hotel's ice church.

However, all the guests keep their winter coats on! Because of all the ice, the temperature inside the

is hotel is always between -2 and $-5^{\circ} \mathrm{C}$. Surprisingly, sleeping is not a problem in the freezing cold hotel rooms. Every guest gets a special cold-weather sleeping bag and some

20 fur blankets. These keep them cozy and warm until morning.

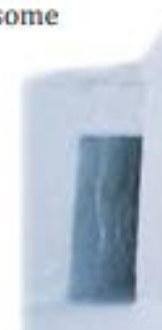

Top-down processing is helpful before reading the text and bottom-up, in turn, is effective while or after reading. Bottom-up processing activities I am giving in this article are to lead students deeper into the details. At the same time these activities help

$$
\begin{aligned}
& \text { check in } \\
& \text { art gallery } \\
& \text { atmosphere } \\
& \text { surprisingly }
\end{aligned}
$$

them learn new words effectively. First, I write new and target words on whiteboard and ask students their translation instead of telling myself. entirely unusual however blanket 
CURRENT RESEARCH JOURNAL OF PHILOLOGICAL SCIENCES 2(12):

155-160, December 2021

DOI: https://doi.org/10.37547/philological-crjps-02-12-30

ISSN 2767-3758

(C)2021 Master Journals

Crossref do

81 Google

Accepted21 $1^{\text {th }}$ December, 2021 \& Published $26^{\text {th }}$ December, 2021

I can tell the translations when students don't know them. Another bottom-up activity is made using web tool www.edu-games.org and are intended to repeat and learn how they are spelt. In my teaching practice, I found out that the more students repeat new and target words, the deeper they understand their meaning and usage in the given text. One of the exercises here is named as word scramble.
Letters of the word is scrambled and students are asked to spell them correctly. The aim of this exercise is to think the spelling and the time they spend on thinking them is crucial in remembering for long time. Another exercise is word search which is made using new and target words from the reading passage. The aim is to help students concentrate on details of the text.

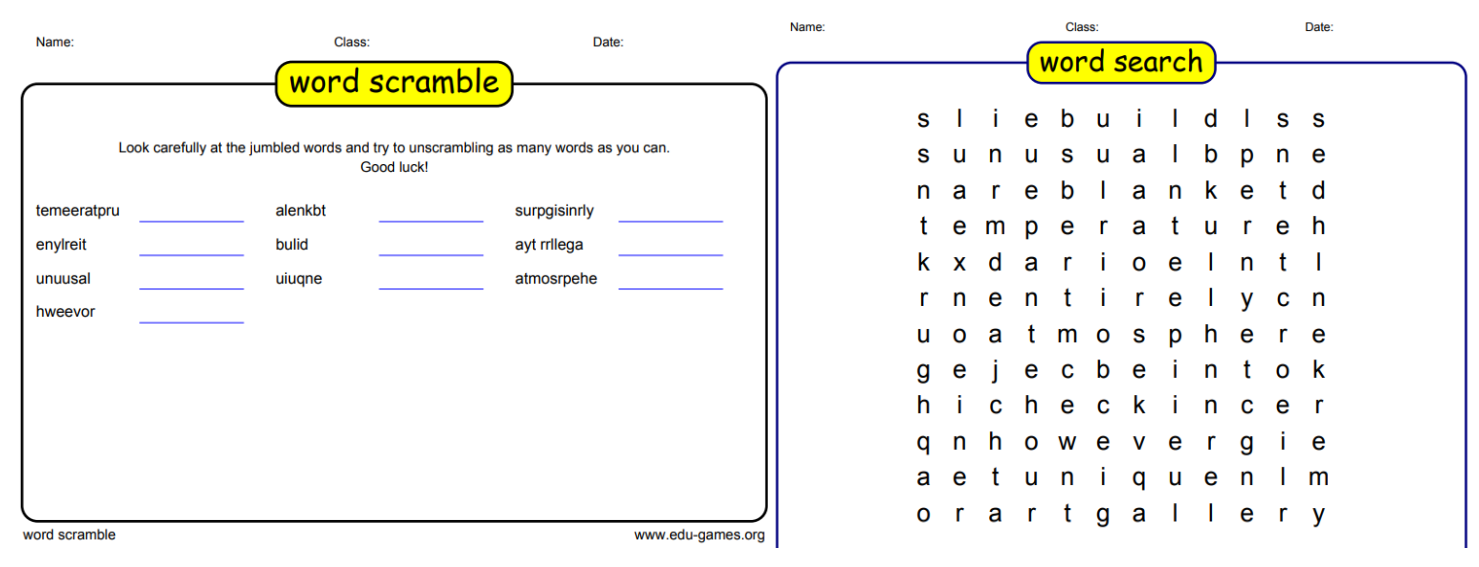

Both top-down and bottom-up processing are helpful in reading and listening in English classes.

\section{Results AND DISCUSSIONS}

When top-down and bottom-up approaches are used in the lessons of English they are effective in terms of language competence is fulfilled. First, students are given the general idea of the text and then they read it. Bottom-up processing is held while or after reading due to the fact that it is about the small details. Results of the lesson with these approaches are usually high. The reading passage is discussed in two ways simultaneously. Some activities are added to increase the level of effectiveness. Another point for discussion is how to use these approaches in real classes. Teacher should pay attention to the reading passage or listening audio's content. Then, he / she chooses activities that best suits to reveal true essence of the content. These approaches can improve students' knowledge in case when teacher prepares suitable exercises to lead towards the main purpose of the reading passage or listening story/lecture.

\section{Conclusion}

Using top-down and bottom-up approaches in English classes is effective when these approaches accompanied by some related activities. In my teaching practice I use these approaches with reading and listening aspects. They are helpful when they are used in turn. The activities given in this article are prepared as sample that can be used in English classes. The activities can be changed according to reading passage's content and topic. 
CURRENT RESEARCH JOURNAL OF PHILOLOGICAL SCIENCES 2(12):

155-160, December 2021

DOI: https://doi.org/10.37547/philological-crjps-02-12-30

ISSN 2767-3758

(C)2021 Master Journals

crossref do) :810 Google

Accepted21 ${ }^{\text {th }}$ December, 2021 \& Published $26^{\text {th }}$ December, 2021

Overall, using these techniques in English classes are effective and can improve learners' knowledge on the topic discussed in short time.

\section{REFERENCES}

1. Anne Anderson \& Tony Lynch. "Listening". Oxford University Press. 1988

2. Claire Elizabeth. "ESL teachers' activities kit". Prentice Hall Direct. New Jersey. 1998

3. Jack Richards. "Designing instructional materials for teaching listening comprehension", in 'The Language Teaching Matrix'. Cambridge. 1990

4. Jill Hadfield. "Advanced Communication Games" Longman Press. New York. 1997

5. Law Barbara. "Assessment and ESL": An Alternative Approach Teachers Guide Edition. Portage \& Main Press. London. 2007

6. Magnus Wilson. "Discovery Listening improving perceptual processing. ELT". Journal Volume 57/4 (October 2003)

7. Mary Underwood. "Teaching Listening". Longman. New York. 1989

8. Murtha Sheila \& Jane Airey O'Connor. "English the American Way: A Fun ESL Guide to Language \& Culture in the U.S”. Research \& Education Association. Washington. 2011

9. Natalie Hess. "Teaching Large Multilevel Classes" Cambridge University Press. Cambridge. 2005

10. Penny Ur. "Teaching Listening Comprehension", Cambridge. 1984

11. Vernon Shelly Ann. "ESL Classroom Activities for Teens and Adults: ESL games, fluency activities and grammar drills for EFL and ESL students". Create Space Independent Publishing Platform. 2012 